\title{
Confronting the 'Fraud Bottleneck': Private Sanctions for Fraud and their Implications for Justice
}

Key words Fraud, private sector, Punishment, Prosecution, Sentencing, Victim

Purpose of this paper The aim of this paper is to illustrate the ways in which contemporary organisations are imposing their own private sanctions on fraudsters.

Design/methodology The research draws on primary data from interviews with counter fraud practitioners in the UK, secondary sources and case examples.

Findings

Such developments have been stimulated, at least in part, by the broader limitations of the criminal justice system and in particular a 'fraud bottleneck'. Alongside criminal sanctions, many examples were provided of organisations employing private prosecutions innovative forms of civil sanction and 'pseudo state' sanctions, most commonly civil penalties comparable to fines.

Research limitations Such changes could mark the beginning of the 'rebirth of private prosecution' and the further expansion of private punishment. Growing private involvement in state sanctions and the development of private sanctions represents a risk to traditional guarantees of justice. There are differences in which comparable frauds are dealt with by corporate bodies and thus considerable inconsistency in sanctions imposed. In contrast with criminal justice measures, there is no rehabilitative element to private sanctions. More research is needed to assess the extent of such measures, and establish what is happening, the wider social implications, and whether greater state regulation is needed.

What is original/

Value of paper

The findings are of relevance to criminal justice policy makers, academics and counter fraud practitioners in the public and private sectors

\section{Article Type: Research paper}

\section{Implications for practice:}

- Private sanctions for fraud are likely to continue to grow, as organisations pursue their own measures rather than relying on increasingly over-stretched criminal justice systems.

- Their emergence, extent and implications are not fully understood by researchers and therefore need much more research, consideration and debate. 
- These private measures need to be more actively recognised by criminal justice policy makers and analysts alongside the already substantial formal involvement of the private sector in punishment through prisons, electronic tagging and probation, for example.

- Such measures lack the checks and balances, and greater degree of consistency as laid out in sentencing guidelines, of the criminal justice system. In light of this, consideration needs to be given to greater state regulation of private sanctions for fraud.

- More also needs to be done to help fraudsters suffering problems such as debt or addiction to rebuild their lives. There is a strong case for measures beyond the criminal justice system to support such fraudsters to be created and publicly promoted.

\section{Introduction}

The emergence of 'private policing' has become a subject of great interest amongst policy makers, researchers and academics. A variety of issues have been explored, including the agents and bodies involved, their culture, their legal powers, their regulation and the social implications of their expansion (Shearing and Stenning, 1981, 1983, 1987; South, 1988; Johnston, 1992; Jones and Newburn, 1998; Loader and Walker, 2001, 2007; Rigakos, 2002; Johnston and Shearing, 2003; Wakefield, 2003; Crawford, Lister and Blackburn, 2005; Button, 2007, 2011; Sarre and Prenzler, 2009; White, 2010). Empirical studies have shown the substantial contribution that the private sector makes to policing internationally in terms of numbers and roles (Shearing, Farnell and Stenning, 1980; Jones and Newburn, 1998; Prenzler, Sarre and Earle, 2008; Confederation of European Security Services, 2011; Nalla and Wakefield, 2014).

There has also been interest in the privatisation of policing (South, 1988; Johnston, 1992; Prenzler, 2004; Wakefield and Button, 2014) and punishment (James, Bottomley, Liebling and Clare, 1997; Sarre, 2001; Mehigan and Rowe, 2007; Shefer and Liebling, 2008; Genders, 2013; Fitzgibbon and Lea, 2014; Ludlow, 2014, 2015). However, interest in the privatisation of punishment has tended to focus upon those areas of the state in which direct 
government policy has led to a transfer of function from the public to the private or voluntary sector, most commonly in relation to prisons, prisoner escort, custody suites and probation. Johnston (1992) associated such developments in UK public policy, many of which have been mirrored internationally, with a 'privatisation mentality' that began under Margaret Thatcher's Conservative government in the 1980s. These amount to what Johnston (1992) would have described as 'direct load shedding' and 'contracting out', whereby the state has deliberately shed roles to the private sector and moved other traditionally state services to private contractors. Such initiatives can also be linked to the concept within the governmentality literature of 'responsibilization', a process in which the state has 'passed back' governance roles that it had previously absorbed to the private and voluntary sectors, including policing and crime prevention functions (O’Malley, 1992; Garland, 1996, O’Malley, 2009).

In The Rebirth of Private Policing, Johnston (1992) also describes a process of 'indirect load shedding', whereby the state, unable to meet public or corporate expectations, is gradually replaced by the private sector filling the gap. Such initiatives have been well documented with regard to areas of policing, such as the patrol of public streets, where the state has not supplied the presence expected. A number of UK studies have exemplified how the private sector (with varying degrees of support from state bodies) has been able to offer this service in residential areas, with the local communities willing to pay for that gap to be filled (McManus, 1995; Noaks, 2000; Sharp and Wilson, 2000; Crawford et al., 2005). Discussion of such trends is developed from an Australian perspective by Prenzler (2004) and a North American viewpoint by Brodeur (2010).

An area in which there has been less academic interest is the 'indirect load shedding' of punishment, although a number of studies have recognised this as occurring with respect to fraud and started to consider its implications. Some three decades ago, Levi (1987, p.183) described prosecution as the 'control method of the last resort' in relation to fraud cases in 
the UK, due to their complexity and expense. He went on to observe that cuts to police resources for the investigation of serious fraud, which was already being de-prioritised at that time in relation to other crimes, shifted 'the economic burden of crime investigation onto victims, especially corporate victims ... and has thus transferred public law back into the sphere of private law' (p.282). Levi, and later Doig and Macaulay (2008), detailed some of the ways in which UK public sector agencies address fraud without involving the police, with the active encouragement of the Parliamentary Committee of Public Accounts (PAC) and the National Audit Office (NAO), by means of their own investigations and criminal prosecutions as well as other forms of sanction. Sarre (2001) considered the implications of using civil and administrative sanctions, as opposed to the criminal law, in relation to a number of areas of criminality, but particularly corporate crime and fraud. The advantages that he noted included efficiency and cost effectiveness, while he also highlighted disadvantages associated with fewer rights for defendants, greater inconsistency in their application, lower visibility and lack of deterrence.

This paper contributes to this small but important body of literature by looking more closely at corporate responses to the punishment of fraud across the private, public and voluntary sectors, and building on Sarre's work to consider the social implications of these responses. Drawing on recent empirical research and legal cases, it will show how the inability of the state to provide for effective criminal sanctions, combined with the desire of many private organisations for a different approach to punishment, is fuelling a growing private involvement in the pursuit and delivery of sanctions. Its extent is such that the corporate sector could be said to be developing a private sanctions framework beyond the state infrastructure. The state has been largely agnostic to such initiatives so far in relation to the private sector, and as such they cannot be viewed as a form of 'responsibilization' - where state encouragement is required. However, they might be viewed as a form of 'self responsibilization' (a concept that has already been raised in a limited way by Yesil, 2006, 
vis-à-vis video surveillance), whereby organisations are reclaiming responsibility from the state when it no longer supports their needs and deciding to take responsibility for punishment themselves. Such conditions are not new, as prior to the formation of the modern police in 1829 (and for some time afterwards), private prosecution was the norm amongst private entities (Johnston, 1992). The initiatives to be described in this paper may, therefore, represent the 'rebirth of private prosecution', and prosecution in a much broader sense of criminal, civil and private sanctions. This represents an additional dimension to the already substantial and growing involvement in private punishment through prisons, tagging and probation.

This paper will illustrate this 'self-responsibilization' or 'indirect load shedding' of punishment in relation to fraud. It will outline the methodology and then present the findings, starting by examining corporate victims in context, before illustrating the macro conditions and in particular the 'fraud bottleneck' that have stimulated such developments The paper will then outline some of the initiatives that organisations are pursuing in order to fill the gap in their punishment needs. In the conclusion the paper will discuss some of the broader implications of these changes, building on the considerations highlighted by Sarre (2001).

\section{Methodology}

This paper draws on the data from a wider research project looking at organisational responses to fraud which involved 39 semi-structured interviews (including five conducted over the telephone). The participants (listed in Figure 1) were practitioners from a variety of public, private and voluntary bodies, from junior to senior, and with some form of counter fraud role. Some of the sectors that were represented included banking, retailing, insurance, building supplies, local government, the National Health Service (NHS), a public transport authority and trade associations. The interviews were also targeted at bodies providing 
services to organisations to deal with fraud such as the police, Crown Prosecution Service (CPS), firms of accountants, lawyers and a private investigator. Some of the telephone interviews related to bodies involved in the investigation and prosecution of healthcare fraud in the United States, where it had been suggested there was innovative use of sanctions.

All five authors undertook interviews with reference to an interview schedule based around a standard set of topics. Among these, participants were asked about their experience of the following, in each case with reference to a common set of prompts:

- Criminal prosecution with official body (CPS, SFO, SOLP)

- Criminal private prosecution

- Civil litigation

- Staff disciplinary procedures

- Use of official regulatory body where possible

- Parallel sanctions

- Other examples of sanctions: UK or overseas

One of the themes that emerged from the research was the diverse and growing range of private sector sanctions deployed to deal with fraud in the absence of an adequate state response. This paper draws upon interview data, documentary material secured during the project and legal cases, as well as other secondary data.

FIGURE 1 ABOUT HERE

\section{Findings}

Corporate Victims in Context 
Over the last two decades there has been a substantial increase in research on victims of crime and an increasing pre-occupation with their needs among policy-makers (Walklate, $2007 a, 2007 b)$. This has been accompanied by a growing punitive orientation among the public and political elites in many Western countries (Garland, 2001; Roberts, Stalans, Indemaur and Hough, 2003). On the other hand, organisations as victims, whether in the public, private or voluntary sectors, have been largely neglected by researchers. Rather, under the auspices of 'white collar crime', the focus has invariably been upon the corporate body as the offender, rather than the victim (Braithwaite, 1984; Croall, 2007; Whyte, 2007; Snell and Tombs, 2011). While there can be little doubt that there is extensive criminal behaviour by corporate bodies, which in most jurisdictions does not receive the attention it deserves, organisations are victims of crime too.

One of the most common crimes they experience is fraud by employees, suppliers, customers and the general population (Levi, 2008). Indeed, in monetary terms it is one of the most - if not the most - expensive crimes to society. In an international survey by the Association of Certified Fraud Examiners (2014), it was estimated that a typical organization loses five per cent of its annual revenue each year to fraud. The average value of a fraud was $\$ 145,000$, while just over a fifth of cases involved losses of at least $\$ 1$ million, and the projected global annual fraud loss was nearly $\$ 3.7$ trillion. In the UK the National Fraud Indicator showed a $f 52$ billion estimated loss in 2012, of which the vast majority can be attributed to private and public organisations (National Fraud Authority, 2013). Research exploring the sanctions that organisations use when targeted has, however, been limited (see Levi, 1987; 1992; 2002; Bussmann and Werle, 2006). One of the few studies that provides clues on a global scale is a somewhat dated international survey of 5,500 companies by Bussmann and Werle (2006). They found that only 51 per cent of cases (both internal and external) led to a criminal charge. Distinct differences were also noted between regions, with Asian companies being much less likely to bring criminal charges (only 26 per 
cent) or terminate employment (68 per cent), and other measures, such as redeployment and warning and indeed doing nothing (16 per cent), being common options.

There has also been a small body of research looking at corporate bodies as forms of governance, examining their internal systems for dealing with deviance, although this has been much broader than fraud and crime more generally (see Shearing and Stenning, 1982; Macauley, 1986; Ayers and Braithwaite, 1995; Johnston and Shearing, 2003). There has, however, been little interest in some of the innovative and most importantly private ways in which corporate bodies are now developing to deal with fraud (as well as some other types of problems). The matter of fraud provides an ideal case study for examining some of these changes. First, it is a major problem to corporate bodies usually in cost and volume of offences (National Fraud Authority, 2013). Second, it is an area in which state resources are thin and, as a consequence, there have been a variety of private initiatives to fill the gap emerging. Before we start to examine these, the methods for this project will be outlined.

The Fraud 'Bottleneck' in the Criminal Justice System.

Fraud is a major problem to the UK economy, with $f 20.2$ billion of the $f 52$ billion cost attributed to the private sector (National Fraud Authority, 2013). Millions of cases of fraud every year are perpetrated against the corporate sector. Many of these are undetected, but there are still many cases that are detected. When frauds are discovered by corporate bodies, it is notable that the range of responses employed extends well beyond those of the criminal justice system. With many internal frauds, the embarrassment and bad publicity that the criminal justice system could potentially bring are one reason why public prosecution may not be sought. Criminal trials often invite media interest and internal frauds often expose poor practices, such as staff incompetence or transgression, and poor supervision. However, even if a corporate body does want to pursue a criminal prosecution, there are a variety of factors that create a 'bottleneck', making it difficult for them to 
achieve that aim.

The police in general devote few resources to fraud and there are less than 700 specialist fraud police officers in the whole of the UK (Button, Blackbourn and Tunley, 2014). This fact, and the lack of political will that lies behind it, can be put into context when one considers the $3000+$ counter fraud specialists employed by the UK's Department for Work and Pensions to address the specific problem of benefit fraud (Button et al., 2014). For many organisations - particularly small and medium sized enterprises - they simply do not have the capacity to launch a criminal investigation (whether it is staff with the skills or resources to hire external investigators). This means that they rely on police interest which, given their resources, is often hard to secure (Fraud Advisory Panel, 2012). Even if an organisation does have the capacity to investigate to a criminal standard, it still requires the support of the police (or other state investigative body) for the case to be accepted and passed on to the prosecutors. Police interest may also be required in order to secure access to their powers of arrest and search. As such, the police represent the gatekeepers to the criminal justice system, but because of the resources and attitudes of some, it is often difficult to obtain their interest, as the quote from one interview illustrates:

(in) this day and age, and I worked in London, and you try and report something to the police and you say, "I've had $£ 4,000$ nicked." And they say, "Yeah, what do you want me to do about it then?" "Well you're the police ain't you?" "£4,000, take it on the chin mate." Building Society Fraud Investigator (Head of Department).

In another interview the long road to justice in some cases that do secure interest was illustrated:

I had another case, it was a middle manager. Daft at it seems, he was using petty 
cash to pay his lifestyle, pay wages of non-existent employees and that sort of thing. The point was the company was in the Midlands, the manager had a branch in Exeter or something. He had to go to the local police and they didn't have a fraud squad and the guy in Exeter was an operational detective and he took on the fraud, but it took him six months, nine months to get round to it because every time he came on duty there was work to do here, work to do there on something else, there was a rape or a murder or a robbery or whatever. So although that guy was willing, keen and able he didn't have the opportunity to be able to do it. Private Investigator.

The position of the police was summed up by one Detective Sergeant from an Economic Crime Team:

[the Economic Crime Team] it's almost like the sickly child, you know, undernourished and under resourced by comparison with more high profile departments. So, you have an issue, there, where demand ... resourcing does not match potential demand, so ... I don't think there is that confidence with the current resourcing that we can adequately ... we do secure many very, very good convictions, but there is that continuing unease ... Police Detective Region 2.

The police, however, are but the first part of the bottleneck. The next is the Crown Prosecution Service (CPS). Some corporate bodies who secure police interest have the case referred to the CPS, who then decide not to continue with the case. Some private bodies have even gone direct to the CPS, as one interviewee who was a CPS lawyer noted:

Occasionally, people will come to us direct and we always explain the difference between the role of the investigator, the role of the prosecutor and refer them back to the police and, usually, they've been to the police already and they're coming to 
us because they haven't had any joy there. CPS Lawyer Local.

Unlike many state bodies (such as the Department for Work and Pensions, HM Revenue and Customs and the NHS) which have developed extensive criminal investigation resources and capacity for their own prosecutions or sections within the CPS, private bodies do not have these luxuries (Button, 2011). There is therefore a 'gap' that has emerged between the demand for criminal sanctions and the capacity of the police to supply these. In such a vacuum, corporate bodies have been developing a variety of mechanisms to sanction fraudsters. In the private sector, however, there is also the strong influence of financial matters, as one consultant providing services to both noted:

Speed of response, corporates want things doing absolutely immediately because the bottom line matters more in corporates. In the public sector they are very keen to see justice done so they would prefer to see somebody put in prison and forget the money has actually gone somewhere and they don't need the money, whereas corporates couldn't give a toss what happened to the person, prison or not prison and would actually prefer not to because of the reputational damage. They are far more interested in, the first question is, "Can you get my money back?" Counter

Fraud Consultant 2.

Numerous studies have noted the variety of employer imposed sanctions used by corporate bodies, including reprimand, taking away privileges, reduced pay through a variety of measures, and dismissal (Macauley, 1986; Goldstraw-White, 2012; Meerts, 2014; Weiss, 2014). These are not controversial. However, as this paper will show, for some corporate bodies these, combined with the absence of a state response, have not satisfied their desire for an effective sanction. As a consequence, a variety of private prosecution and private sanctions have emerged on top of these traditional sanctions, which will now be explored. 
Filling the Gap

Many private sector bodies have been finding new means to sanction fraudsters, some of which use state structures, while others employ new privately developed structures. It is important to note that generalisation is difficult as the use of such measures varies considerably within the private sector.

Criminal sanctions remain attractive to many private organisations, providing the ultimate deterrent to other potential fraudsters. Initiating criminal proceedings can also bring the perpetrator to the negotiating table (Williams, 2014), as one interviewee noted:

The Chief Exec had suspected that the Finance Director was messing about with the funds. He did not know what was happening but he knew there was a big hole in the accounts. That was as much as he knew, so we sent in one of our investigators and one of our forensic accountants when he wasn't in, on a Friday.... It was such an easy one to spot because we just went straight into his internet activity and he was doing online bingo, constantly. I mean a bloke, online bingo. He spent over $f 700,000$ of the company's money on online bingo at work. By the Sunday afternoon we had actually got his house signed over. We had gone round to see him and basically said, "This is ugly, could go to the police." And he just said, "OK" and literally signed over his house to the company. Counter Fraud Consultant 2.

However, it is also clear that among some sections of commerce there is an appetite for new measures in the knowledge that the traditional state centred approach cannot satisfy their needs. As one investigator from the financial services sector succinctly summed up: 
Fraud Investigator (Head of Department).

Some organisations have therefore sought to develop their own means to guarantee that criminal prosecution is on the negotiating table, most notably through private prosecution.

\section{Private prosecutions}

The right to pursue a private prosecution in England and Wales is set out in section 6 of the Prosecution of Offences Act 1985 (see Lewis, Brooks, Button, Shepherd and Wakefield, 2014, in relation to fraud). There is evidence of growing interest and use of private prosecution. There has been media coverage exposing the willingness of companies such as Virgin Media to pursue private prosecutions and high profile cases such as the conviction of Kenyan businessman Ketan Somaia for a \$19.5 million fraud by private prosecution in 2014 (Dodd, 2014; Croft, 2014). There are also law firms that have emerged offering this service, such as Edward Hayes and one firm, Edmunds Marshall McMahon, specialising purely in private prosecutions for corporate victims (Edmunds Marshall McMahon, 2015). Ernst and Young, one of the major accountancy firms, has also launched a private prosecution service for clients in 2014 in partnership with Peters and Peters Solicitors (Croft and Binham, 2014). Some corporate victims have turned to firms such as these when there has been police interest, but the CPS has declined to prosecute. For example, two interviewees from two different anti-piracy bodies both claimed the CPS had been reluctant to take forward some cases of copyright infringement related crimes, but corporate willingness to fund a private prosecution had encouraged the police to remain involved when possible CPS non involvement may have reduced their commitment to remain involved. In other cases the organisation had been determined to secure what they regarded as a far more effective sanction despite the lack of CPS interest. The case of one anti-piracy unit head who used a private prosecution illustrates this: 
... and all that happened, every time they got served with some civil letters, they folded, moved off and set up a new company in a false name. So they were spending a fortune constantly trying to redo it, and send people after them. And one of them got chatting to me, and I said, 'why don't we just go criminally?' It's absolutely a clear criminal case; let's just arrest them for conspiracy to defraud. So again, engaged with local law enforcement, they were arrested for that, convicted at court and also with the Proceeds of Crime [Act], so double whammy. I think he got three years or three and a half years, so a substantial sentence. Anti-Piracy Unit 3 Head.

It is difficult to determine the extent of private prosecutions in England and Wales, because no statistics are kept by the CPS. Given that Edmunds Marshall McMahon was only established in 2012, there have not been significant numbers prior to this, but the formation of such firms and other significant entrances to the market illustrates that this is an area that may begin to grow. However, it is clear that private prosecution is growing as an option amongst corporate bodies.

The privatisation of prosecution raises some interesting issues for debate. The constitutional division between the prosecutor and investigator in criminal cases is much cherished. This becomes blurred when the client becomes the paymaster for both. There is of course the right of the state to take over a private prosecution and discontinue it, which happened to Edmunds Marshall McMahon on one occasion (Edmonds and McMahon, 2014). However, if such cases expand, it remains to be seen how adequate such measures will be and whether the CPS will be able to cope if there are large numbers of private prosecutions occurring.

Innovative civil sanctions

The use of the civil justice system by corporate victims is another important tool, which 
provides for an option in parallel to criminal proceedings or quite often alone (Meerts and Dorn, 2009; Meerts, 2014). The lawyers specialising in civil fraud interviewed for this research all noted that many corporate bodies will use the civil process to secure recompense and compensation from the perpetrator, particularly when they hold assets such as property, investments or a pension fund. Cases pursued through the civil courts also enable a wide range of orders to be granted which can act as sanctions (such as freezing a bank account or confiscating a passport) and powers for the purposes of an investigation (such as searches). The way statistics are compiled by the Ministry of Justice means exact figures are impossible to secure. It is clear that there are thousands of such cases every year, most settled out of court, and that this is still a significant and especially common private sanction open to corporate victims to pursue for large fraud losses.

Some corporate bodies also pursue regulatory sanctions against fraudsters. Fraudsters who work in roles where they require an official licence to operate, such as accountants, lawyers and surveyors, are often pursued through their regulatory bodies with the aim of having them 'struck off' as a means of sanction, which also serves as a tactic to bring the culprit to the negotiating table. The extent of such sanctions, however, is difficult to determine.

One area of the civil law that has been utilised very innovatively by some insurance company victims relates to contempt of court (Button and Brooks, 2014). There are two categories of contempt of court, criminal and civil. The criminal form is concerned with direct contempt of court involving, for example, interrupting Crown Court proceedings, threatening witnesses or disobeying court orders. Civil contempt is usually concerned with the failure to comply with court orders and is a means to enforce remedies such as injunctions or compensation orders. The civil form is quasi-criminal in nature as the penalty is up to two years' imprisonment and the burden of proof is to the criminal standard, beyond reasonable doubt. An unusual feature of the offence is that it is not tried before a 
jury.

A particular species of civil contempt has been gaining momentum over the last few years in dealing with insurance fraud. The Civil Procedure Rule 32.14 provides that:

Proceedings for contempt of court may be brought against a person if he makes, or causes to be made, a false statement in a document verified by a statement of truth without an honest belief in its truth (Ministry of Justice, 2015).

The landmark case sparking this tool for insurers was Joanne Kirk v Carol Walton [2008] EWHC 1780 and [2009] EWHC 703 (QB). In this case, Joanne Kirk claimed that an accident in which her car experienced a rear end shunt had triggered health complaints leading to the inability to walk more than ten yards, and caused her to have to give up work. She initially claimed for $£ 800,000$ but eventually settled for $£ 25,000$ compensation, which she received. The insurers in this case, RBS, commissioned private investigators to put Kirk under surveillance and secured footage of her walking, shopping and driving. As a result, they sought grounds to bring contempt proceedings against her for 'making false statements'. The case was heard in March 2009 and she was found in contempt on two grounds of lying in court documents. Her penalty was to pay for her legal bill of $£ 125,000$, half the defendant's legal costs and a f2500 fine (Guildhall Chambers, 2015).

In another case, Nield v Loveday [2011] EWHC 2324, Acromas Insurance used the contempt of court route. A couple had sought to claim substantial personal injury damages for a car accident. The claim was shown to be fraudulent and Acromas, through the law firm Keoghs, brought successful contempt of court proceedings leading to a nine month prison sentence for the husband and six months suspended for 18 months for the wife (Keoghs, 2011). It is very difficult to estimate the total number of these types of case, as there are no clear 
statistics published and not all cases may be reported by the media. However, it is clear that this is becoming a service actively promoted by some firms, as the following extract from an article by a Director at solicitors DWF reveals:

As well as providing a remedy for fabricated incidents ... contempt proceedings are an ideal remedy for exaggerated claims, which currently fall outside the acceptance criteria for IFED [Insurance Fraud Enforcement Bureau], the specialist police unit dedicated to tackling insurance fraud.

It goes on to state,

The days when dishonest claimants who are found out can simply walk away from their actions are over. Procedures are in place to enable fraudsters to be punished and our experienced specialists are ready to use them. Delay is the enemy in this jurisdiction. The process is quick and relatively inexpensive and it is difficult to imagine a more potent counter fraud message to send fraudsters than they risk losing their freedom. (Palmer, 2012)

It is difficult to determine the extent of this sanction because the Ministry of Justice does not keep statistics linked to this species of contempt. However, searches through the media coverage of insurers and lawyers would suggest that there have been dozens of cases since the Kirk case. The small number might lead one to consider it as not being significant.

However, the development of this sanction poses some interesting issues for debate. It provides for the potential for serious criminal-like penalties without some of the fundamental guarantees of criminal courts, such as trial by jury. As with private prosecution, the divisions between investigation and prosecution that occur in the criminal 
arena also become blurred in contempt cases. Insurers effectively assume both roles, as the clients with the resources and ability to task their legal and investigation teams to pursue proceedings. Unlike private prosecutions, however, there is no scope for the state to take over cases to discontinue them.

'Pseudo state' sanctions

The sanctions gap has also created the development of what could be described as 'pseudo state' sanctions since they are comparable to some state sanctions. The most common are civil penalties which compare to fines. Civil penalties have become particularly popular in the retail sector for shoplifting as well as some fraud related offences (Bamfield, 2012; Citizen Advice, 2009). Under these schemes, instead of an offender being pursued in the criminal courts, culprits are issued with a letter seeking compensation for the goods stolen and time taken by the organisation to investigate the matter. Another area in which such approaches have been used is against those suspected of downloading music illegally. The law firm ACS: Law secured much publicity when, on behalf of MediaCAT, it began issuing thousands of civil penalty letters to individuals suspected of downloading music illegally, demanding $f 500$ or the prospect of court action (Wakefield, 2011). Many of those receiving letters claimed to be innocent and the firm eventually stopped doing this, while the managing partner of the firm faced disciplinary action from the Solicitors Regulatory Authority. There has also been criticism of those using these measures for demanding payments well in excess of the actual loss, as well as for targeting minors (Citizen Advice, 2009).

There are a variety of fraudster databases that could be compared to the UK's state run Violent and Sex Offender Register, but which are managed by private sector consortiums. They are often marketed as 'preventative tools' rather than punishment, but they do have 
implications for individuals listed on the register, as has been noted in research on more illicit blacklists (Whyte, 2015). The consequences of being placed on these fraudster lists include greater difficulties in securing employment and/or costs in gaining financial products, and therefore must be seen as a form of punishment. For example, an individual placed upon the Insurance Fraud Register might find it difficult to secure motor insurance or the costs may become prohibitive, making lawful driving impossible for many. There are a number of bodies holding databases with details of individuals convicted of, dismissed from employment for, or suspected of fraud, some of the most prominent of which are listed in Figure 1. These vary in their coverage and the criteria for individuals included upon them. For example, the Staff Fraud Database maintained by CIFAS (a membership association for fraud prevention, formerly known as the Credit Industry Fraud Avoidance Service) has the following criteria for inclusion on its database:

Factual Accuracy and Standard of Proof In order to file a staff fraud record, the information must be factually correct and accurate. A member filing such information can only do so if it has good reason to believe it has or could have suffered loss, and/or it reasonably believes that it has grounds to press criminal charges for fraud or the commission of any other offence if a suspect were traced. This means that in all cases, members MUST be prepared to make a formal complaint to the police or other relevant law enforcement agency. Members must have carried out checks of sufficient depth to satisfy this standard of proof (and must retain a record of the checks). The criminal offence must be identifiable (Personal Communication from CIFAS).

In general, the administrators of these schemes argue that they are fraud prevention tools, enabling their corporate users to prevent 'known fraudsters' gaining employment or access to their services. They do, however, have consequences for those registered on such 
databases, who may find it more difficult to access services such as credit, financial products or insurance, or secure a job. Indeed, the Insurance Fraud Register has been upfront about the sanctions element to the scheme, noting in its launch statement:

It is up to each individual insurer to decide how the information on the register is used; there is no common approach agreed across the industry; each insurer is at liberty to adopt its own approach. Insurers may wish to apply special terms to proven fraudsters, decline to accept them as new customers or decline to invite renewal of a product. Proven insurance fraudsters will find it harder to buy new products and to renew their existing products. They may also find it more difficult to obtain other financial services, including loans and mortgages (Out-Law.Com, 2012).

Little is known about the quality of the decision-making and the potential to review decisions which are wrong. Most would regard the inclusion of those who have been convicted of fraud in court as uncontentious, but the vast majority of these entries are decided by the member organisation with no reference to an official court decision. The question can also be raised as to what happens when someone makes a genuine mistake or omits information in the rush of a credit application and, as a consequence, is added to one of these databases based upon the decision of the corporate body with no opportunity for the 'fraudster' to challenge the decision. Indeed, in 2014 a case was highlighted of a man who failed to notify his mortgage lender that he was letting some of his spare rooms and, as a consequence, was placed on the CIFAS fraudster database on the grounds of 'application fraud and mortgage property misuse' (Mikhailova, 2014).

In another case in 2012 the BBC's Money Box programme highlighted the case of a student who had been placed on the CIFAS fraudster database for 'first party fraud' by mistake, and who as a consequence had his existing bank accounts closed and was unable to open 
another account. The student complained, 'I was made to go to the counter and clear my account in cash. You feel like a criminal when you're marched over and marched out the door without being given any reason as to why your account is being closed' (BBC News, 2012). Only his father's intervention and investigation skills saved him as he was able to prove it was the bank's mistake. The Chair of the then Financial Services Authority's Consumer Panel, commented upon the case, 'You cannot find out what you're accused of, you cannot plead your case and you find yourself unable to open a bank account and nothing can be done about it. What's happening goes absolutely against the rules of natural justice' (BBC News, 2012).

The implications for an individual in their access to a range of services, securing a job and the plain label of 'fraudster' could be significant. In short, the definitions of a fraudster and determining who is labelled as such are becoming privatised and fragmented with corporate bodies determining the definitions and decisions with no reference to the state. There are a variety of definitions of what constitutes fraud, different levels of proof and multiple bodies presiding over the decisions. The consequence is a corporate sector that, in effect, has created its own system for determining and sanctioning fraudsters, operating on a mass scale. As Figure 2 illustrates, some of these databases contain hundreds of thousands of entries. Such measures may also represent a form of shaming in a manner that brings stigma rather than being ultimately re-integrative, as Braithwaite (1989) viewed the process of criminal sanction.

FIGURE 2 ABOUT HERE

\section{Discussion}

[There was] little or no attempt at criminal detection. Crime was brought to the 
courts when victims prosecuted offenders. Officials did not go out to find it. Justices dealt with the evidence, but detection and apprehension was left to the victims, who often went to great lengths to regain stolen property ... (Johnston, 1992: 9).

The quote by Johnston above refers to the policing and justice system of the late eighteenth and early nineteenth centuries. Those comments could also be applied to many of the arrangements in the private sector for dealing with fraud today. The emergence of private sector interventions to fill the gap and develop new private solutions amounts to the 'indirect load shedding' of the state or 'self-responsibilization' of punishment. To adapt the title of Johnston's book, we could be experiencing the 'rebirth of private prosecution' and further expansion of private punishment, added to the already substantial involvement of the private sector in punishment through prisons, tagging, probation, etc. In the UK, many of these changes have only recently occurred. The first contempt of court case for insurance fraud was in 2008, the specialist legal practice Edmunds Marshall McMahon was established in 2012, and the National Fraud Register in 2012; other initiatives such as the CIFAS Staff Fraud Database date back to 1988 . As such the life of such measures may be limited; because they are so new they may not sustain enough support for them to continue. However, given that the underpinning conditions that have caused them are unlikely to go away, it seems likely they will continue to grow in the UK, and that this trend could well be replicated in other jurisdictions. Their emergence and implications are not fully understood by researchers and therefore need much more consideration and debate, building on Sarre's (2001) earlier work relating to civil and administrative responses to crimes more generally.

First of all, as Sarre highlighted, the growing range of private involvement in state sanctions and the development of private sanctions represent a risk to the traditional guarantees of justice. The blurring of investigatory and prosecution decisions under the client's purse with 
respect to private prosecution and contempt of court measures present a significant risk. Justice comes much more under commercial influence and away from an independent system built upon separation of powers. The proliferation of private pseudo justice beyond the criminal justice system also does not provide for the same checks and balances. At the pinnacle is the criminal justice system, with its extensive procedures, standards and balanced legal representation, set against a cacophony of other forums or in many cases just a decision-maker to determine guilt with very mixed standards of justice. Even the civil justice system does not guarantee legal representation for the accused. Some of the other sanctions, such as fraudsters' databases, could be considered as the summary justice of the corporate state with little support available to help the defendant. For example, if an employee is sacked for a fraud that they dispute and is placed on a fraudster's register, there is no guarantee of support for the accused to defend or challenge such decisions, when such a person might be incapable of defending themselves or have no opportunity to do so. Inclusion on such lists for many will have significant implications for their lives.

The changes also highlight the clear differences in which comparable frauds are dealt with by corporate bodies and the consequent inconsistency in sanctions imposed, a problem also recognised by Sarre (2001) with respect to civil and administrative sanctions. Some comparable fraudsters may face a significantly different range of sanctions, with some facing the traditional criminal justice system, others the civil and pseudo measures and others presented with all of these. Consistency in sentencing in the criminal courts has been a subject of much debate and reform (Ashworth, 2007; Van Slyke and Bales, 2012). However, given the small number of fraud cases that ultimately end up in the criminal courts, such initiatives to create sentencing consistency seem futile when so many other sanctions are happening around them with no attempt to obtain consistency. 
Another important implication of the use of non-criminal sanctions is that it signals the rejection of rehabilitation. There is much to be debated concerning the commitment and effectiveness of such measures within the criminal justice system (Zedner, 2004). But what is clear with the use of many of the sanctions described in this paper is the complete absence of any interest in rehabilitation. Fraudsters who may have significant personal problems that led them to commit fraud are likely to receive no help if they are dealt with outside the criminal justice system. Although many such fraudsters may be at low risk of reoffending, the rise of the non-criminal infrastructure, built upon situational principles of protecting the organisation, not society, does not provide for any rehabilitation. More needs to be done to focus on measures to help fraudsters suffering problems such as debt or addiction to rebuild their lives. Measures to help such fraudsters need to be created beyond the criminal justice system and publicly promoted.

The 'rebirth of private prosecution' and the growing addition to the already growing private punishment infrastructure, occurring with the 'self-responsibilization' of punishment, have significant consequences that raise a wide range of issues for debate. It particularly requires more research to assess the extent of such measures (on which, as has been noted in this article, there is not much data at present), establish what is happening, their wider implications for society and, most importantly, whether greater state regulation of them needs to occur.

\section{References}

Ashworth, A. (2007), "Sentencing", in Maguire, M., Morgan, R. and Reiner, R. (Eds), The Oxford Handbook of Criminology (4th ed), Oxford University Press, Oxford.

Association of Certified Fraud Examiners (2014), Report to the Nations on Occupational Fraud and Abuse: 2014 Global Fraud Study, Austin, TX, Association of Certified Fraud Examiners.

Ayers, I. and Braithwaite, J. (1995), Responsive Regulation, Oxford: Oxford University Press.

Bamfield, J. (2012) Shopping and Crime, Palgrave, Basingstoke. 
BBC News (2012, "Bank account closures 'unjust'”, available from http://www.bbc.co.uk/news/business-18540832.

Braithwaite J. (1984), Corporate Crime in the Pharmaceutical Industry, Routledge and Keegan Paul, London.

Braithwaite, J. (1989), Crime, Shame and Integration, Cambridge University Press, Cambridge.

Bussmann, K.-D. and Werle, M. (2006), “Addressing crime in companies: first findings from a global survey of economic crime", British Journal of Criminology, 46(6): 1128-1144. Button, M. (2007), Security Officers and Policing: Powers, Culture and Control in the Governance of Private Space, Ashgate, Aldershot.

Button, M. (2011), Doing Security: Critical Reflections and an Agenda for Change, Basingstoke, Palgrave Macmillan.

Button, M. (2011), “Fraud investigation and the 'flawed architecture' of counter fraud entities in the United Kingdom“, International Journal of Law Crime and Justice, 39(4): 249-265.

Button, M. and Brooks, G. (2014), “From 'shallow' to 'deep' policing: 'crash-for-cash' insurance fraud investigation in England and Wales and the need for greater regulation", Policing and Society, DOI: 10.1080/10439463.2014.942847 Button, M., Blackbourn, D. and Tunley, M. (2014) “The not so thin blue line after all?' investigative resources dedicated to fighting fraud/economic crime in the United Kingdom", Policing: A Journal of Policy and Practice, doi: 10.1093/police/pau037. Citizens Advice (2009), “Unreasonable demands? Threatened civil recovery against those accused of shoplifting oremployee theft", Available at: https://www.citizensadvice.org.uk/global/migrated_documents/corporate/unreason able-demands-final.pdf. Confederation of European Security Services (2011), Private Security Services in Europe: COESS Facts and Figures 2011, Wemmel, Belgium, CoESS. 
Crawford, A., Lister, S., and Blackburn, S. (2005), Plural Policing: The Mixed Economy of Visible Patrols in England and Wales, Policy Press, Bristol.

Croall, H. (2007), "Victims of white collar and corporate crime", in Davies, P., Francis, P. and

Greer, C. (Eds) Victims, Crime and Society, Sage, London.

Croft, J. and Binham, C. (2014) "EY to offer businesses help with private prosecutions for fraud", Financial Times, 20 November 2014, available at http://www.ft.com/cms/s/0/14317698-700a-11e4-bc6a 00144feabdc0.html\#axzz3OodMSSkg.

Croft, J. (2014), "Private prosecutions grow as state bodies retreat in face of dwindling resources", available from http://www.ft.com/cms/s/0/0e0368e0-11bd-11e4-a17a 00144feabdc0.html\#axzz3PSFS7mct.

Dodd, V. (2014), "Metropolitan Police accused of acting on behalf of big business", available from http://www.theguardian.com/uk-news/2014/jan/29/metropolitan-police virgin-media-lord-chief-justice.

Doig, A. and Macaulay, M. (2008), "Decades, directions and the fraud review: addressing the future of public sector fraud?" Public Money and Management, 28:3, 185-192.

Edmonds, T. and McMahon, K. (2014), "Private prosecutions for fraud", paper presented at the 2014 Counter Fraud and Forensic Accountants Conference, University of Portsmouth, 3rd June 2014, available from

http://videoupload.port.ac.uk/upload/showvid.php?id=139ad8b7-3a7c-4788-8ed8 $9 c 9 b 56 f c 986 b$

Edmunds Marshall McMahon (2015) Home page, available from http://www.emmlegal.com.

Fitzgibbon, W. and Lea, L. (2014), "Defending probation: Beyond privatisation and security", European Journal of Probation, 6: 24-41

Fraud Advisory Panel (2012), Understanding Fraud Suffered by individuals and Smaller Businesses, Fraud Advisory Panel, London. 
Garland, D. (1996), 'The limits of the sovereign state: strategies of crime control in contemporary society', British Journal of Criminology, 35 (4), 445-71.

Garland, D. (2001), The Culture of Control: Crime and Social Order in Contemporary Britain, University of Chicago Press, Chicago.

Genders, E. (2013), "Prisons and privatisation: policy, practice and evaluation", in Dockley, A. and Loader, I. (Eds) The Penal Landscape: The Howard League Guide to Criminal Justice in England and Wales, London, Routledge.

Goldstraw-White, J. (2012. White-Collar Crime.Accounts of Offending Behaviour, Palgrave, Basingstoke.

Guildhall Chambers (2015), Conniving, Collusion and Contempt, available from:

http://www.guildhallchambers.co.uk/uploads/docs/section9/Connivingcollusioncont empJCB.pdf.

James, A.J., Bottomley, A.K., Liebling, A. and Clare, E. (1997. Privatizing Prisons: Rhetoric or Reality, Sage, London.

Johnston, L. and Shearing, C., D. (2003), Governing Security, Routledge, London. Johnston, L. (1992), The Rebirth of Private Policing, Routledge, London. Jones, T. and Newburn, T. (1998), Private Security and Public Policing, Clarendon Press, Oxford.

Keoghs (2011), Client Alert - Stark Warning Given to Fraudsters, available from :http://www.keoghs.co.uk/files/Client_Alerts/2011/Client_Alert_ _Loveday_decision_July_2011.pdf.

Levi, M. (1987), Regulating Fraud: White-Collar Crime and the Criminal Process, London: Routledge.

Levi, M. (1992), The Investigation, Prosecution and Trial of Serious Fraud, London: HMSO. Levi, M. (2002), "Suite justice or sweet charity? Some explorations of shaming and incapacitating business fraudsters", Punishment and Society, 4(2): 147-63. Levi, M. (2008), “Organized frauds and organising frauds: unpacking the research on 
networks and organisation", Criminology and Criminal Justice 8(4):389-419.

Lewis, C., Brooks, G., Button, M., Shepherd, D. and Wakefield, A. (2014), “Evaluating the case for greater use of private prosecutions in England and Wales for fraud

offences". International Journal of Law, Crime and Justice, 42, 3-15.

Loader, I. (2000), 'Plural policing and democratic governance', Social and Legal Studies, 9: 323-345.

Loader, I. and Walker, N. (2001), 'Policing as a public good: reconstituting the connections between policing and the state', Theoretical Criminology, 5(1): 9-35.

Loader, I. and Walker, N. (2007), Civilising Security, Cambridge, Cambridge University Press. Ludlow, A. (2014), "Transforming rehabilitation: what lessons might be learned from prison privatisation?", European Journal of Probation, Vol. 6 No. 1, 67-81.

Ludlow, A. (2015), Privatising Public Prisons: Labour Law and the Public Procurement Process, Oxford, Hart Publishing.

Macauley, S. (1986), "Private government", in Lipson, L. and Wheeler, S. (eds.) Law and the Social Sciences, Russell Sage Foundation, New York.

McManus, M. (1995), From Fate to Choice: Private Bobbies, Public Beats, Aldershot, Avebury.

Meerts, C. and Dorn, N. (2009), “Corporate security and private justice: danger signs?", European Journal of Crime, Criminal Law and Justice, 17: 97-111.

Meerts, C. (2014), "Corporate security: governing through private and public law", in Walby, K. and Lippert, R. (Eds) Corporate Security in the 21st Century, Basingstoke, Palgrave. Mehigan, J. and Rowe, A. (2007). Problematizing prison privatization: an overview of the debate. In: Jewkes, Yvonne ed. Handbook on Prisons. Cullompton: Willan, pp. 356376.

Mikhailova, A. (2014), "I ended up on a fraud list for letting rooms", Sunday Times, 16 February, available at http://www.thesundaytimes.co.uk/sto/business/money/mortgage_and_property/ar 
ticle1375628.ece.

Ministry of Justice (2015), Evidence, available at:

http://www.justice.gov.uk/courts/procedure-rules/civil/rules/part32\#IDA5SOHC.

Nalla, M. and Wakefield, A. (2014), 'The security officer' in M. Gill (ed.) The Handbook of Security (2nd ed), Basingstoke, Palgrave Macmillan.

National Fraud Authority (2013), Annual Fraud Indicator, NFA, London.

Noaks, L. (2000), 'Private cops on the block: a review of the role of private security in residential communities', Policing and Society, 10: 143-161.

O’Malley, P. (1992), ‘Risk, power and crime prevention', Economy and Society, 21(3): 25275.

O'Malley, P. (2009), 'Responsibilization' in Wakefield, A. and Fleming, J. (eds.) The Sage Dictionary of Policing, London: Sage Publications.

Out-Law.Com (2012), Insurance Fraud Register Launched to Aid Crackdown on Fake Claims, available from: http://www.out-law.com/en/articles/2012/september/insurance fraud-register-launched-to-aid-crackdown-on-fake-claims/.

Palmer, J. (2012), “Fraudsters found guilty of contempt of court and sentenced to imprisonment", Mondaq, available from http://www.mondaq.com/x/190460/Personal+Injury/Fraudsters+Found+Guilty+Of+ Contempt+Of+Court+And+Sentenced+To+Imprisonment.

Prenzler, T. (2004), 'The privatization of policing' in R. Sarre and J. Tomaino (eds) Key Issues in Criminal Justice, Unley, SA, Australian Humanities Press.

Prenzler, T. (2006), "Private investigators”, in Gill, M. (Ed.) The Handbook of Security (1st ed), Palgrave, Basingstoke.

Prenzler, T., Sarre, R., \& Earle, K. (2008), "Developments in the Australian security industry", Flinders Journal of Law Reform, 10(3), 403-417.

Rigakos, G.S. (2002), The New Parapolice: Risk Markets and Commodified Social Control, Toronto: University of Toronto Press.

Roberts, J., Stalans, J., Indemaur, D. and Hough, M. (2003), Penal Populism and Public 
Opinion: Lessons from Five Countries, Oxford University Press, New York.

Sarre, R.and Prenzler, T. (2009) The Law of Private Security in Australia (2nd ed), Sydney, Thomson Reuters.

Sarre, R. (2001), 'Alternatives to the criminal courts: some considerations of civil and administrative options in the process of legal regulation', Caribbean Law Review, 11(1), 25-38.

Sharp, D. and Wilson, D. (2000), 'Household security': private policing and vigilantism in Doncaster', Howard Journal, 39: 113-131.

Shearing, C.D. and Stenning, P.C. (1981) 'Modern private security: its growth and implications', Tonry, M. and Morris, N. (eds.) Crime and Justice: An Annual Review of Research Vol. 3, Chicago, University of Chicago Press.

Shearing, C.D. and Stenning P.C. (1982), Private Security and Private Justice, Montreal: Institute on Public Policy.

Shearing, C.D. and Stenning, P.C. (1983) 'Private security: implications for social control', Social Problems, 30:5, 493-506.

Shearing, C.D. and Stenning, P.C. (1987. Private Policing. Newbury Park: Sage.

Shearing, C.D., Farnell, M.B. and Stenning, P.C. (1980), Contract Security in Ontario, Toronto, Centre of Criminology, University of Toronto.

Shefer, G. and Liebling, A. (2008), "Prison privatisation: in search of a business-like atmosphere?", Criminology and Criminal Justice, 8(3): 261-278.

Page 26 of 30Journal of Criminological Research, Policy and Practice Snell, K. and Tombs, S. (2011), “How to get your voice heard when no one will let you?' victimisation at work", Criminology and Criminal Justice, 11(3): 207-223. South, N. (1988), Policing for Profit, Sage, London. Tombs, S. and Whyte, D. (2007), Safety Crimes, Willan, Cullompton. Van Slyke, S. and Bales, W., D. (2012), "A contemporary study of the decision to incarcerate white-collar and street property offenders", Punishment and Society 14(2): 217-246. 
Wakefield, A. (2003), Selling Security: The Private Policing of Public Space, Willan,

Cullompton.

Wakefield, A. and Button, M. (2014), "Private policing in public spaces" in Kane, R. and Reisig, M. (Eds) The Oxford Handbook of Police and Policing, New York, Oxford University Press.

Wakefield, J. (2011), “Law firm ACS: Law stops chasing 'illegal file sharers'”, BBC News, 25 January, available from http://www.bbc.co.uk/news/technology-12253746.

Weiss, R.P. (2014) “Corporate security at Ford Motor Company: from the Great War to the Cold War", in, Walby, K. and Lippert, R. (Eds) Corporate Security in the Twenty First Century, Palgrave, Basingstoke.

White, A. (2010) The Politics of Private Security: Regulation, Reform and Re-Legitimation, Basingstoke, Palgrave.

Whyte, D. (2007) "Victims of corporate crime", in Walklate, S. (Ed) Handbook of Victims and Victimology, Willan, Cullompton.

Whyte, D. (2015) “Policing for Whom?” Howard Journal, 54 (1): 73-90.

Williams, J. W. (2014), "The private eyes of corporate culture: the forensic accounting and corporate investigation industry and the production of corporate financial security", in Walby, K. and Lippert, R. (eds) Corporate Security in the Twenty-First Century, Palgrave, Basingstoke.

Yesil, B. (2006), "Watching ourselves: video surveillance, urban space and self responsibilization", Cultural Studies, 20 (4-5): 400-416.

Zedner, L. (2004), Criminal Justice, Oxford University Press, Oxford. 
Figure 1. Interviewees (with assigned name used) contacted for this research

\section{Criminal Justice System}

Crown Prosecution Service national

Crown Prosecution Service local

Serious Fraud Office (SFO) representative

Police detective region 1

Police detective region 2

Police detective London

Police detective London

\section{Civil System}

Lawyer specialising in fraud

Lawyer 2 Bevan Brittan (specifically asked for firm to be named)

Lawyer 3 Bevan Brittan (specifically asked for firm to be named)

\section{Counter Fraud Bodies}

National Fraud Authority Official

Anti-fraud NGO chair

Fraud NGO official

\section{Public Sector}

Public corporation security manager

Department for Business, Innovation and Skills investigator

NHS counter fraud specialist

London Borough counter fraud specialist

Regional local authority counter fraud specialist

Trading standards officer 
Transport body security manager

\section{Private Sector}

Counter fraud consultant 1

Counter fraud consultant 2

Private investigator (ex-fraud police)

Building society fraud investigator (ex-fraud police)

Building supplies manager (business controls and procedures manager)

Company head (self-investigator)

High street bank fraud investigator.

Supermarket head of security

Media company investigations manager

\section{Other Sectors}

RSPCA prosecutor

Anti-piracy unit 1 director general

Anti-piracy unit 2 acting head

Anti-piracy unit 3 head

Parking association

Parking enforcement company

Retail civil recovery expert

USA

US federal fraud investigator

US federal prosecutor east coast

US federal prosecutor deep south 
Figure 2. Fraudster databases

\section{Staff Fraud Databases}

CIFAS Staff Fraud Database

Contains around 1000 names of individuals who have been convicted of fraud or equivalent (see above) who are added by members. Members, over which there are over 160, have access to this database and can make entries. This database is largely orientated around financial services.

Telecommunications UK Fraud forum (TUFF) Information on Ex-Employees Database

A database covering details of staff of member organisations who have been dismissed for theft or fraud.

\section{Fraud Databases}

\section{CIFAS National Fraud Database}

This is a much larger database containing information relating to confirmed and attempted frauds largely relating to financial applications (for example for credit, loans or products purchased on contract or in instalments). It has over 250,000 records and $250+$ member organisations.

\section{Experian National Fraud Database}

Contains fraud information relating to addresses, social security numbers, driving licences and phone numbers. 
against insurers. 